\title{
Rancang Bangun Sistem Aplikasi Tanggap Cepat Pengaduan Infrastruktur Berbasis Android pada Dinas Pekerjaan Umum dan Penataan Ruang Kota Malang
}

\author{
Meyti Eka Apriyani a,1,*, Imam Fahrur Rozi ${ }^{2}$, Mahanani Nur Budiarti , Anita Ivianti 4 \\ a Politeknik Negeri Malang, Soekarno Hatta, Malang, Indonesia \\ ${ }^{1}$ meyti24@gmail.com*; ${ }^{2}$ imam.rozi@polinema.ac.id; \\ * Penulis Korespondensi
}

\begin{abstract}
Abstrak
Banyaknya permasalahan mengenai infrastruktur yang terjadi di Kota Malang menjadi kendala majunya suatu pemerintahan kota. Untuk menyampaikan permasalahan dari masyarakat kepada pemerintahnya perlu adanya suatu fasilitas atau media. Fasilitas ini diharapkan membantu menguhubungkan antara masyarakat dengan pemerintah kota dengan lebih efektif dan efisien. Berkenaan degan hal tersebut, sangat diperlukan suatu aplikasi untuk menunjang penyampaian aspirasi masyarakat. Aplikasi tersebut berupa aplikasi mobile yang dapat diakses oleh masyarakat secara langsung sehingga nantinya pengaduan dan keluhan dari masyarakat akan ditangani secara cepat oleh Dinas Pekerjaan Umum dan Perumahan Rakyat (Dinas PUPR). Pada penelitian ini sebanyak 30 orang yang telah menggunakan aplikasi ini, sebesar $83 \%$ mengatakan setuju bahwa adanya aplikasi ini dapat membantu pelaporan kerusakan infrastruktur di Kota Malang. Berdasarkan hal tersebut dapat disimpulkan bahwa aplikasi ini dapat mempermudah masyarakat dalam pengaduan terkait infrastruktur dan juga dapat membantu Dinas PUPR dalam menerima aduan masyarakat dan penyaluran aduan ke bidang yang menanganinya.
\end{abstract}

Kata Kunci: Dinas PUPR, Malang, SIGAP, Tanggap cepat

\section{Pendahuluan}

Pelayanan publik adalah pemenuhan keinginan dan kebutuhan masyarakat oleh penyelenggara negara. Negara didirikan oleh publik (masyarakat) tentu saja dengan tujuan agar dapat meningkatkan kesejahteraan masyarakat [1].

Sebagai salah satu bentuk tanggung jawab pemerintah kepada masyarakat, sudah tentunya suatu pelayanan publik yang diselenggarakan pemerintah harus mencakup seluruh masyarakat yang membutuhkannya, dan yang paling penting lagi adalah bagaimana masyarakat dapat menyampaikan aspirasi dan keluhan yang dirasakannya serta tanggapan yang cepat dari aparat yang berwenang.

Banyaknya permasalahan mengenai infrastruktur yang terjadi di masyarakat Kota Malang menjadi kendala majunya suatu pemerintahan kota. Untuk menyampaikan permasalahan dari masyarakat kepada pemerintahnya perlu adanya suatu fasilitas. Fasilitas ini diharapkan membantu menguhubungkan antara masyarakat dengan pemerintah kotanya seefektif dan seefisien mungkin. Pada kenyataannya masyarakat masih sulit dalam menyampaikan pengaduan kepada pemerintah Kota Malang. Apabila pengaduan permasalahan masih bersifat manual maka waktu yang dipergunakan akan tidak efisien. Baik bagi pemerintah maupun masyarakat itu sendiri. Serta Masyarakat tidak tahu tindak lanjut dan respon dari pihak yang bertanggung jawab atas permasalahan tersebut.

Untuk mengatasi masalah tersebut agar lebih mudah dan efisien dalam melakukan pengaduan atau keluhan, sangat diperlukan aplikasi untuk menunjang penyampaian aspirasi masyarakat. Aplikasi tersebut berupa aplikasi mobile yang dapat diakses oleh masyarakat secara langsung dan 
nantinya pengaduan dan keluhan dari masyarakat akan ditangani langsung oleh Dinas Pekerjaan Umum dan Penataan Ruang.

Maka dengan adanya layanan dengan pemanfaatan aplikasi ini, diharapkan dapat membantu masyarakat dalam menyalurkan pengaduan atau keluhan yang mereka adukan ke pihak yang bersangkutan. Serta Masyrakat akan mendapatkan feedback dari Dinas Pekerjaan Umum dan Penataan Ruang yaitu dengan dapat memonitoring secara langsung progres dari laporan keluhan yang mereka kirimkan.

\section{Landasan Teori}

\subsection{Kajian penelitian terdahulu}

Perancangan sistem pengaduan berbasis web ini memudah mahasiswa Universitas Mercu Buana Kranggan dalam membuat pengaduan terhadap pihak kampus dan meminimalisir waktu bagi mahasiswa tanpa harus ke ruang Humas [2]. Aplikasi yang dirancang ini dapat menjadi solusi untuk pihak kampus supaya bisa merubah proses bisnis pengaduan yang dijalankan manual menjadi terkomputerisasi Rancangan sistem ini bisa di gunakan untuk mahasiswa yang berada disekitar kampus yang ingin membuat pengaduan, melihat proses pengaduan yang sudah di tindaklanjuti, memberi tanggapan terhadap respon Humas dan juga memberi rating terhadap pengaduan yang sudah selesai di proses.

Terdapat tiga komponen utama dalam penelitian ini diantaranya:

1. Pelayanan publik, yaitu sangat erat kaitannya dengan pemerintah, karena salah satu tanggung jawab pemerintah ialah memberikan pelayanan kepada masyarakat [1]. Kualitas pelayanan publik yang diterima masyarakat secara langsung dapat dijadikan tolak ukur dalam menilai kualitas pemerintah. Pelayanan publik dalam perkembangannya timbul dari adanya kewajiban sebagai suatu proses penyelenggaraan kegiatan pemerintahan baik yang bersifat individual maupun kelompok.

2. MySQL, merupakan Database Server yang bersifat Open Source, Multiplatform dan Berbasis database relasional [3]. MySQL dapat dipakai untuk database pribadi atau pada level korporat berskala kecil hingga besar. MySQL menggunakan SQL untuk mendukung pengaksesan data (query),

3. CodeIgniter, yaitu sebuah framework atau biasa disebut kerangka kerja, dimana cara kerjanya membagi antara unit kontrol, unit data/model dan unit tampilan/view, CodeIgniter sangat popular dikalangan developer web dikarenakan sifatnya terbuka dan multi platform sehingga ringan dan mudah untuk digunakan [4].

\subsection{Framework CodeIgniter}

CodeIgniter merupakan sebuah framework yang dibuat dengan menggunakan bahasa PHP, yang dapat digunakan untuk pengembangan web secara cepat. Adapun framework sendiri dapat diartikan sebagai suatu struktur pustaka-pustaka, kelas-kelas dan infrastruktur run-time yang dapat digunakan oleh programmer untuk mengembangkan aplikasi web secara cepat. Tujuan penggunaan framework adalah untuk mempermudah pengembang web mengembangkan aplikasi web yang robust secara cepat tanpa kehilangan fleksibilitas [5].

\section{Metode}

\subsection{Metode Pengumpulan Data}

Pada pembuatan aplikasi ini menggunakan teknik pengambilan data berdasarkan wawancara atau korespondensi kepada pihak yang menangani tentang pengaduan maysrakat yaitu kepala Dinas Pekerjaan Umum dan Penataan Ruang Kota Malang. Metode ini meminta informasi dari sampel pertama untuk mendapatkan sampel berikutnya, demikian secara terus menerus hingga seluruh kebutuhan sampel penelitian dapat terpenuhi. Dalam pengambilan data ketika wawancara kepada Kepala Dinas Pekerjaan Umum dan Penataan Ruang Kota Malang, Dinas Pekerjaan Umum dan 
Penataan Ruang Kota Malang. Dari bidang - bidang yang terdapat di Dinas Pekerjaan Umum dan Penataan Ruang Kota Malang maka diambil lima bidang yang akan dapat dilaporkan melalui aplikasi ini. Yaitu bidang cipta karya, bidang bina marga, bidang sumberdaya air dan drainase, bidang air minum dan air limbah dan bidang tata ruang.

\subsection{Metode Perancangan Sistem}

Metode yang digunakan dalam Aplikasi Tanggap Cepat Pengaduan Infastruktur di Kota Malang ini adalah SDLC (System Development Life Cycle) dengan model waterfall. Sedangkan dalam pengumpulan data adalah menggunakan metode wawancara mendalam dan observasi langsung. Namun dalam penerapan metode ini hanya melakukan sampai tahap Integration and System Testing / pengujian program. Proses Operation and Maintenance dilakukan jika aplikasi ini sudah dioperasikan secara resmi pada Dinas Perumahan Rakyat dan Penataan Ruang Kota Malang.

Penjelasan dari tahap tahap waterfall model sebagai berikut :

\section{a. Requirements Definition}

Merupakan proses pengumpulan kebutuhan piranti lunak. Pembuatan sebuah piranti lunak dapat di mulai dengan melihat dan mencari apa yang di butuhkan oleh sistem. Proses pengumpulan kebutuhan dilakukan secara intensif untuk menspesifikasikan kebutuhan perangkat lunak agar dapat di pahami oleh user. Dari kebutuhan sistem tersebut akan diterapkan kedalam piranti lunak yang di buat.

\section{b. System and Sotfware Design}

Perancangan piranti lunak merupakan proses terhadap yang memfokuskan pada desain pembuatan program perangkat lunak termasuk struktur data, arsitektur perangkat lunak, refresentasi antarmuka, dan prosedure pengodean.

\section{c. Implementation and unit testing.}

Pada tahap ini,Sistem sudah siap diterapkan atau sudah mulai siap digunakan oleh pengguna sehingga tidak ada lagi kesalahan ketika sistem sudah diimplementasikan

\section{d. Pengujian}

Pada tahap ini program yang telah dibuat harus diuji coba agar tidak terjadi error dan hasilnya harus sesuai dengan kebutuhan yang telah didefinisikan

\section{e. Operasi dan Maintenance}

Ini merupakan tahap terakhir dalam model waterfall. Software yang sudah jadi dijalankan serta dilakukan pemeliharaan. Pemeliharaan termasuk dalam memperbaiki kesalahan yang tidak ditemukan pada langkah sebelumnya

\subsection{Analisa Kebutuhan}

Aplikasi yang akan dibuat merupakan sebuah aplikasi berbasis android. Dimana user atau pelapor dapat melakukan pengaduan/keluhan tentang infrastruktur yang berada di Kota Malang. Dalam aplikasi ini, user dapat melakukan pengaduan secara online melalui handphone. Saat user menggunakan aplikasi tersebut, user perlu memasukan data diri sebelum dapat memasukan alamat dari lokasi yang dilaporkan dengan bantuan Maps yang telah disediakan, nama laporan, deskripsi laporan, dan upload foto dengan bantuan kamera. Seperti terlihat pada gambar di bawah ini : 


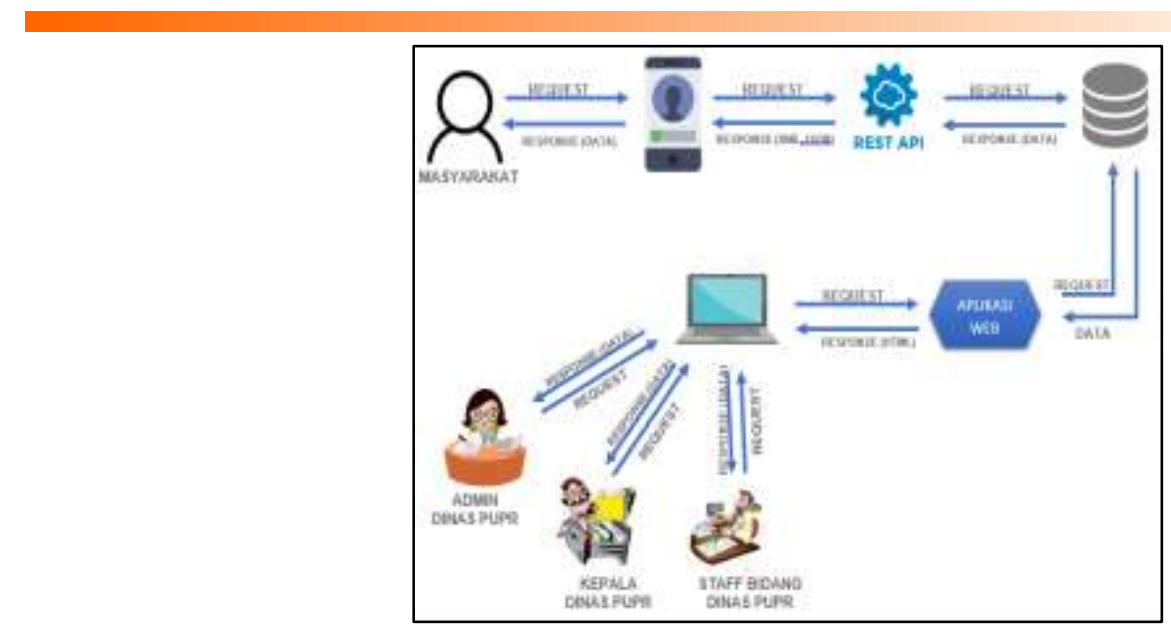

Gambar 1. Alur aduan melalui sistem

Gambar 1 merupakan alur aduan melalui sistem, kemudian, admin bertugas untuk menerima laporan dari user dan memfilter laporan tersebut melalui halaman website Admin. Setelah memfilter laporan yang benar - benar valid dari user, admin meneruskan laporan ke Kepala Dinas lalu Kepala Dinas akan memilih staff bagian bidang yang sesuai untuk menangani laporan tersebut. Setelah laporan sampai ke staff bagian maka staf bagian akan memberikan tanggapan dan progres pengerjaan dari laporan yang dikirimkan masyrakat secara berkala melalui aplikasi tersebut.

\subsection{Analisa Sistem}

Aplikasi yang akan dibuat merupakan sebuah aplikasi berbasis android. Dimana user atau pelapor dapat melakukan pengaduan/keluhan tentang infrastruktur yang berada di Kota Malang. Dalam aplikasi ini, user dapat melakukan pengaduan secara online melalui handphone. Saat user menggunakan aplikasi tersebut, user perlu memasukan data diri sebelum dapat memasukan alamat dari lokasi yang dilaporkan dengan bantuan Maps yang telah disediakan, nama laporan, deskripsi laporan, dan upload foto dengan bantuan kamera.

\subsection{Analisis Kebutuhan Data}

Aplikasi Tanggap Cepat Pengaduan Infrastruktur di Kota Malang yang akan dibangun berbasis website dan mobile untuk mempermudah penyampaian aspirasi masyarakat Kota Malang. Dalam pengembangan sistem ini, dibutuhkan beberapa data input, antara lain:

a. Data user yang akan dikelompokan berdasarkan level seperti admin, kepala dinas, staff bagian dan mayarakat seperti nama, no identitas, ussername, password, alamat.

b. Data laporan untuk dapat melakukan pelaporan seperti lokasi kejadian, deskripsi, judul laporan, katagori, tanggal laporan.

c. Data Tanggapan dari admin website seperti balasan dan progres

d. Data Masyarakat yang digunakan untuk proses login, register, dan proses tambah laporan atau aduan pada sistem.

e. Data Status digunakan untuk menginputkan status apa saja yang akan digunakan dalam proses disposisi laporan atau aduan masyarakat.

f. Data Bidang berisi nama-nama bidang apa saja yang ada di Dinas PUPR

g. Data Staf berisi nama-nama staf yang bekerja di Dinas PUPR

h. Data Level berisi level atau kategori user pada sistem website.

\subsection{Work Breakdown Structure (WBS)}

Work breakdown structure adalah suatu metode pengorganisasian proyek menjadi struktur pelaporan hierarakis. WBS digunakan untuk melakukan Breakdown atau memecahkan tiap proses 
pekerjaan menjadi lebih detail hal ini dimaksudkan agar proses perencanaan proyek memiliki tingkat yang lebih baik.

Pada WBS diatas terdapat 3 task dengan masing-masing task memiliki subtask yang berbeda. Pada task 1 data memiliki 4 subtask yaitu Data Pelapor, Data Laporan, dan Data Tanggapan yang merupakan data-data yang akan digunakan dalam pembuatan aplikasi. Task 2 layanan yang memiliki dua subtask yaitu android dan website. Dan masing-masing subtask tersebut memiliki work package yang berbeda.

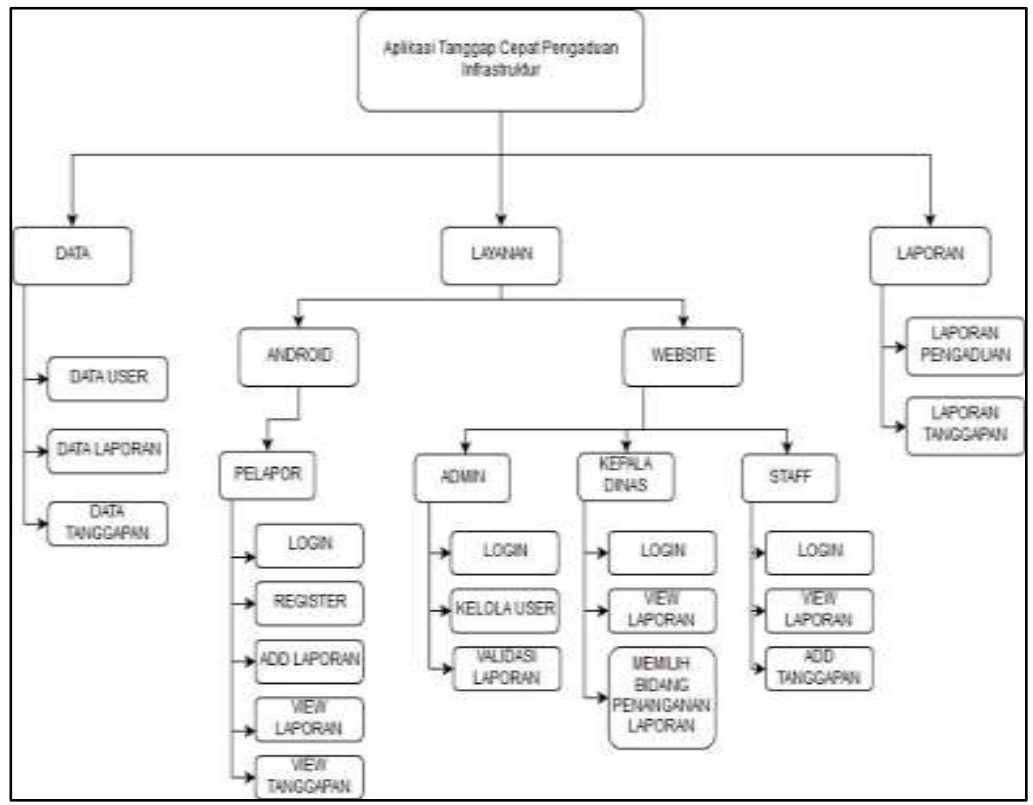

Gambar 2. Work Breakdown Structure (WBS)

Gambar 2 diatas merupakan gambar dari Work Breakdown Structure. Task 2 layanan yang memiliki dua subtask yaitu android dan website. Dan masing-masing subtask tersebut memiliki work package yang berbeda.

a. Subtask 2.1 yaitu Android, bagian ini menggambarkan fitur-fitur apa saja yang dapat digunakan oleh user dalam aplikasi android. Pada subtask Android memiliki satu work package yaitu Pelapor. Di dalam work package Pelapor terdapat fitur login, register, add laporan, view laporan, dan view tanggapan.

b. Subtask 2.2 yaitu Website, bagian ini menggambarkan fitur-fitur apa saja yang dapat digunakan oleh user.

c. Work Package 2.2.1 yaitu Admin yang memiliki fitur login, register, add laporan, view laporan, dan view tanggapan.

d. Work Package 2.2.2 yaitu Kepala Dinas yang memiliki fitur login, view laporan, dan memilih bidang penanganan laporan.

e. Task 3 Laporan memiliki 2 subtask yaitu Laporan Pengaduan yang berisikan laporan pengaduan dari para user dan Laporan Tanggapan berisikan laporan tanggapan yang telah ditambahkan oleh admin

\section{Hasil dan Pembahasan}

\subsection{Use Case Diagram}

Use case diagram adalah gambaran graphical dari beberapa atau semua actor, use case, dan interaksi diantaranya yang memperkenalkan suatu sistem. Use case diagram hanya memberi 
gambaran singkat hubungan antara usecase, aktor, dan sistem. Pada gambar ini adalah usecase diagram system

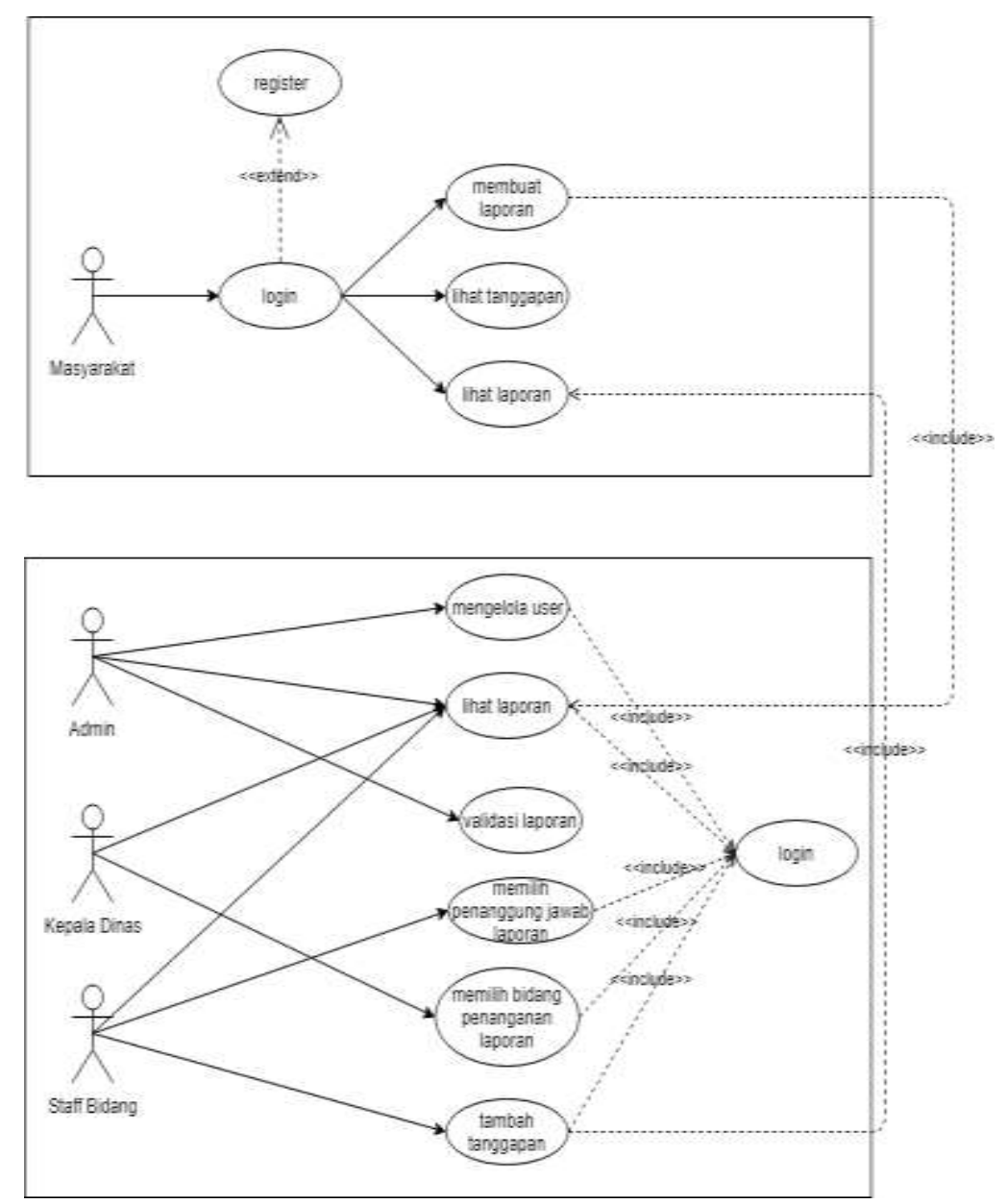

Gambar 3. Usecase Diagram

Gambar 3 merupakan gambar dari usecase diagram. Usecase terdiri dari 4 aktor yang terdiri dari masyarakat, admin, kepala dinas dan staf bidang. Dengan memiliki fungsi masing masing aktor dalam usecase berperan sangat penting di dalam sistem.

\subsection{Implementasi Basis Data}

Pembuatan database pada sistem ini menggunakan mysql phpmyadmin dengan nama database "lapor". Pada database yang akan digunakan terdapat 8 tabel yanag akan ditujukan pada gambar 4 berikut : 


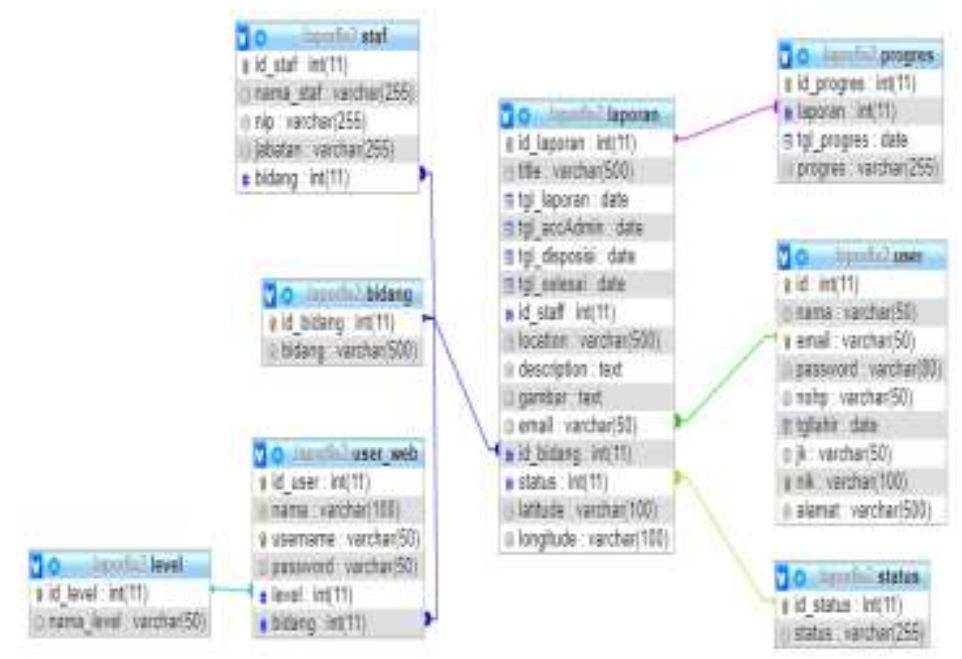

Gambar 4. Struktur Database SIGAP

\subsection{Implementasi Aplikasi}

Pada penelitian ini, implementasi terdiri dari spesifikasi sistem, implementasi kode, data, dan implementasi antarmuka.

\subsubsection{Implementasi Antarmuka}

Pada menu Dashboard, terdapat beberapa task dan jumlah data di tiap task tersebut. Diantaranya task data laporan yang berisi jumlah dari tabel laporan, task total user masyarakat yang menunjukan jumlah user masyarakat yang telah menggunakan aplikasi SIGAP di android, task total respon menunjukan jumlah dari tabel progres, dan task total staf menunjukan banyaknya jumlah staf di tiap bidang Dinas Pekerjaan Umum dan Pekerjaan Ruang. Pada gambar 5 merupakan tampilan menu dashboard Admin

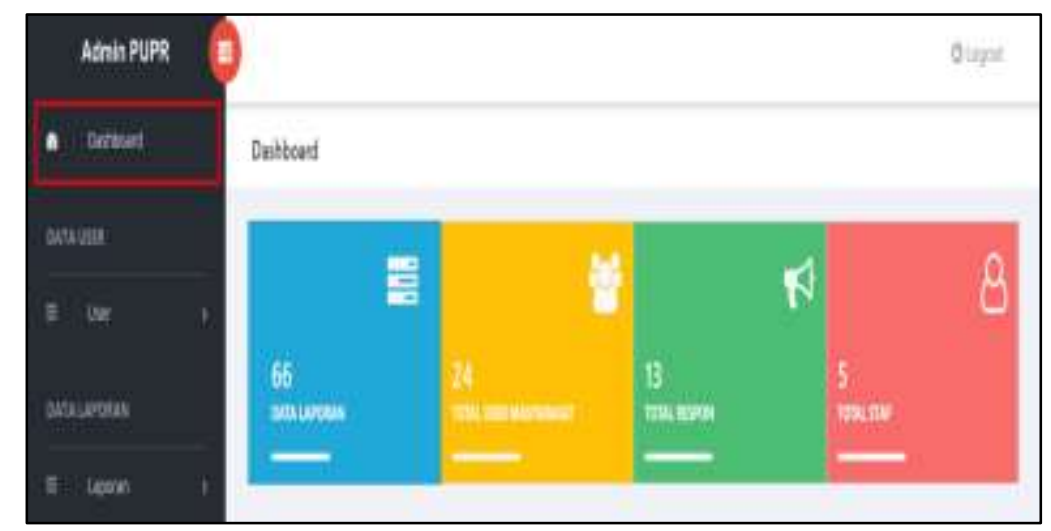

Gambar 5. Halaman Dashboard

Menu data laporan Baru digunakan untuk menampilkan tabel data dari laporan yang baru saja dikirimkan oleh masyarakat dan belum diolah oleh Admin. Di dalam data laporan admin juga dapat mengelola atau memfilter laporan. Pada gambar 6 merupakan tampilan dari data laporan baru yang baru dikirm oleh masyarakat pada halaman admin. 


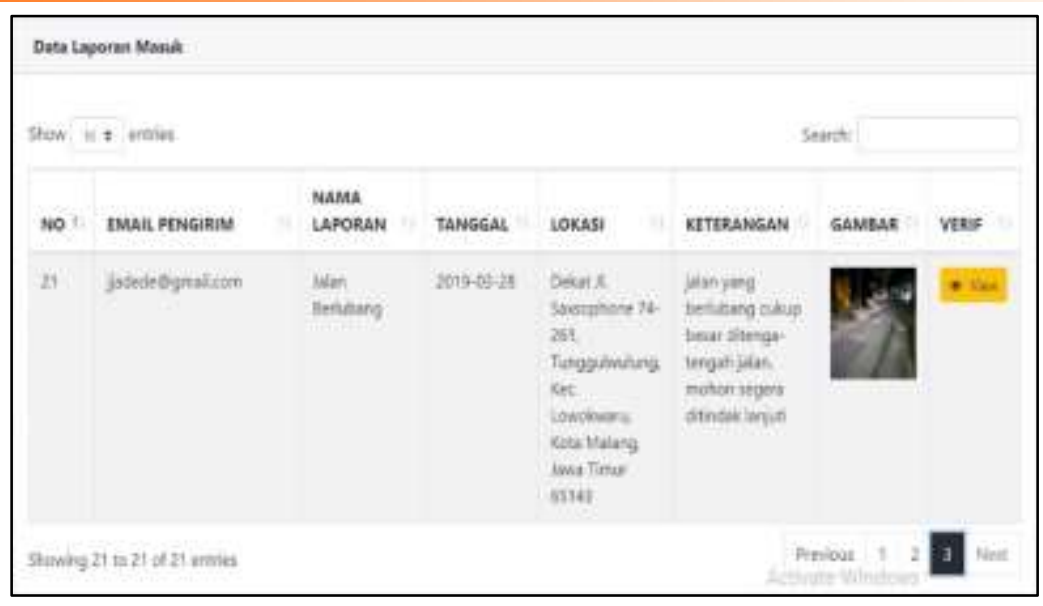

Gambar 6. Menu data Laporan

Button View digunakan untuk melihat detail dari data laporan, dan juga Admin dapat mengolah data yang masuk dengan mengubah status laporan. Status laporan dengan status Diverfikasi maka laporan akan masuk ke dalam sistem Kepala Dinas, sebaliknya status Ditolak maka laporan tidak akan masuk ke sistem Kepala Dinas. Jika admin selesai mengolah data laporan yang masuk, klik button Submit.

Halaman data laporan digunakan untuk menampilkan semua data laporan y ang telah diinputkan oleh masyarakat atau pelapor. Pada gambar 7 merupakan gambar tabel data laporan pada halaman admin.

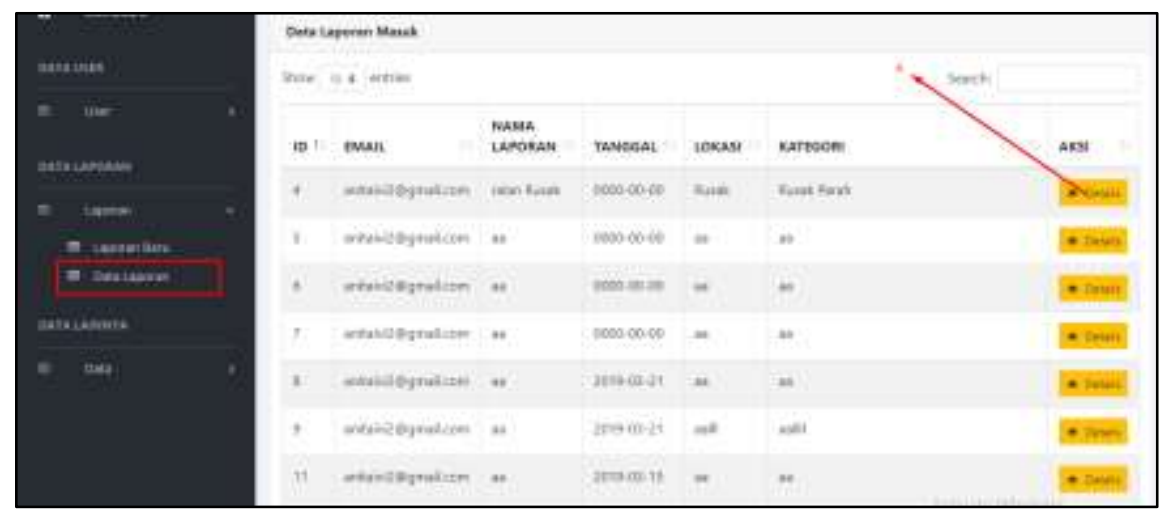

Gambar 7. Menu tabel data laporan

\subsubsection{Implementasi Android}

Halaman splash screen digunakan sebagai tampilan utama dan pengenalan dari aplikasi. Pada gambar di bawah ini merupakan tampilan per-slide splash screen pada android 


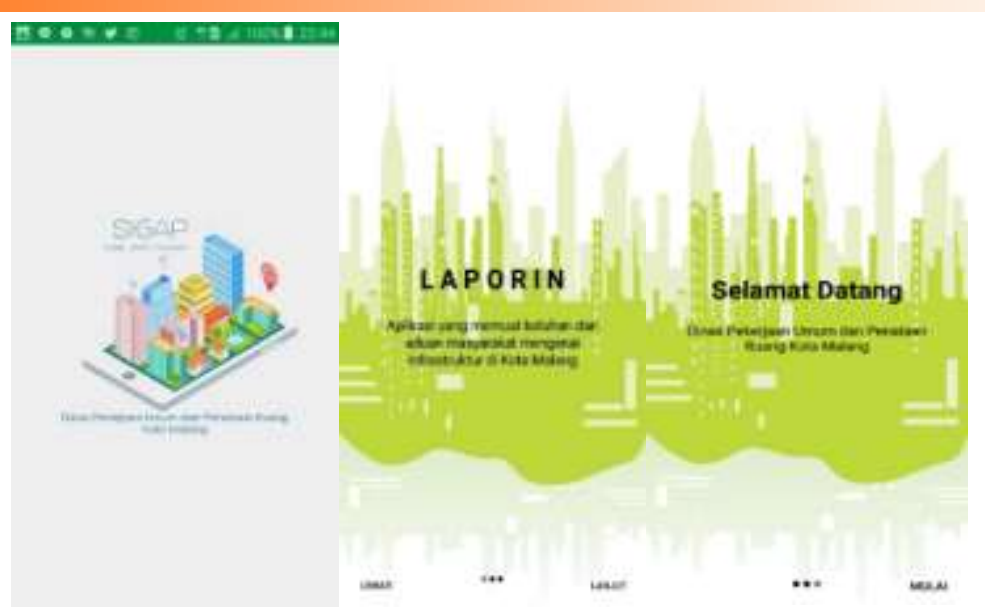

Gambar 8.Splash Screen

Halaman awal dari aplikasi ini yaitu data laporan yang masuk dari semua masyarakat yang telah diverifikasi oleh admin.Sehingga masyarakat umum dapat melihat laporan-laporan yang telah masuk. Kemudian jika masyarakat ingin menambah laporan dapat menekan button yang ada di kanan bawah. Dashboard digunakan untuk menampilkan menu-menu yang tersedia pada sistem. Pada gambar 9 merupakan tampilan dashboard ketika masyarakat berhasil melakukan registrasi.

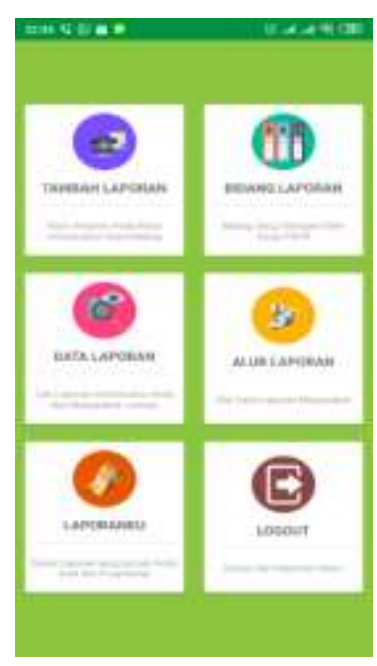

Gambar 9. Dashboard

Halaman Data Laporan berisikan data-data laporan dari semua user yang telah memasukan keluhan atau laporan pada sistem. Untuk melihat lebih lengkap tetang laporan - laporan yang dikirim klik gambar laporan. Lalu anda dapat melihat Tampilan gambar detail laporan yang dapat dibaca oleh user. Pada gambar 10 merupakan tampilan list laporan masyarakat dan detail laporan. 


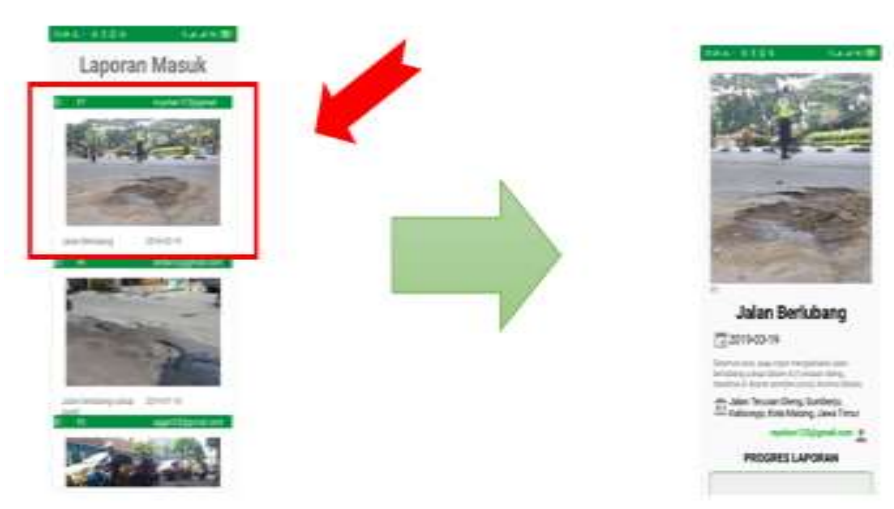

Gambar 10. Halaman Data Laporan Android

\subsection{Pengujian Aplikasi}

\subsubsection{Blackbox Testing}

Tabel 1 merupakan hasil dari pengujian dengan menggunakan BlackBox Testing, untuk mengetahui sejauhmana tampilan dan unjuk kerja serta responsibilitas sistem pada saat dipergunakan oleh user.

Tabel 1. Testing

\begin{tabular}{lll}
\hline $\mathbf{N o}$ & Skenario & Kesimpulan \\
\hline $\mathbf{1}$ & User login dengan memasukkan username dan password & Valid \\
\hline $\mathbf{2}$ & User masyarakat menginputkan laporan & Valid \\
\hline $\mathbf{3}$ & Admin mengelola user, memvalidasi laporan & Valid \\
\hline $\mathbf{4}$ & $\begin{array}{l}\text { User kepala dinas dapat melihat laporan pengaduan dan memilih bidang } \\
\text { penanganan laporan }\end{array}$ & Valid \\
\hline $\mathbf{5}$ & $\begin{array}{l}\text { User staf bidang dapat melihat laporan, memilih penanggung jawab dan } \\
\text { menambah tanggapan }\end{array}$ & Valid \\
\hline
\end{tabular}

\subsubsection{Hasil Tes responden}

Pengujian dilakukandengan menggunakan angket yang disebar kepada responden sebanyak 30 responden. Hasil penyebaran angket diperoleh hasil seperti ditunjukkan sebagai berikut:

Tabel 2. Interval Penilaian

\begin{tabular}{lll}
\hline Indeks & Rentang & Keterangan \\
\hline 1 & $0 \%-19,99 \%$ & Sangat tidak setuju \\
\hline 2 & $20 \%-39,99 \%$ & Tidak Setuju \\
\hline 3 & $40 \%-59,99 \%$ & Cukup \\
\hline 4 & $60 \%-79,99 \%$ & Setuju \\
\hline 5 & $80 \%-100 \%$ & Sangat setuju \\
\hline
\end{tabular}

Tabel 2 merupakan interval penilaian dari hasil pengujian yang dibagikan kepada responden terhadap penilain sistem

Tabel 3 skor

\begin{tabular}{|c|c|c|c|c|c|c|}
\hline \multirow[t]{2}{*}{ No } & \multirow[t]{2}{*}{ Pertanyaan } & \multicolumn{5}{|c|}{ Tanggapan } \\
\hline & & STS & TS & C & $S$ & SS \\
\hline 1 & Aplikasi berjalan baik pada perangkat & & & & & 3 \\
\hline 2 & $\begin{array}{l}\text { Tampilan pada aplikasi ini mudah } \\
\text { digunakan }\end{array}$ & & & & 1 & 2 \\
\hline
\end{tabular}




\begin{tabular}{llll}
$\mathbf{3}$ & $\begin{array}{l}\text { Aplikasi dapat membantu para staff, } \\
\text { admin, dan kepala dinas dalam } \\
\text { mengelola aduan masyarakat yang } \\
\text { masuk }\end{array}$ & 2 & 1 \\
$\mathbf{4}$ & $\begin{array}{l}\text { Fitur - fitur yang ada dalam aplikasi ini } \\
\text { dapat berjalan dengan baik }\end{array}$ & 2 & 1 \\
\hline
\end{tabular}

Dari beberapa kuesioner yang diberikan kepada petugas Dinas Pekerjaan Umum dan Penataan Ruang Kota Malang, maka data yang dapat diambil adalah :

1. Pengguna mengatakan sangat setuju bahwa aplikasi dapat berjalan baik pada perangkat yaitu sebesar $100 \%$.

2. Pengguna mengatakan setuju pada tampilan aplikasi ini mudah digunakan yaitu sebesar $33,3 \%$. Selanjutnya, pengguna mengatakan sangat setuju pada tampilan aplikasi ini mudah digunakan yaitu sebesar 66,7\%.

3. Pengguna mengatakan setuju pada aplikasi yang dapat membantu para staff, admin, dan kepala dinas dalam mengelola aduan masyarakat yang masuk yaitu sebesar 66,7\%, sedangkan pengguna mengatakan sangat setuju pada aplikasi yang dapat membantu para staff, admin, dan kepala dinas dalam mengelola aduan masyarakat yang masuk yaitu sebesar $33,3 \%$

4. Pengguna mengatakan setuju pada fitur - fitur yang ada dalam aplikasi ini dapat berjalan dengan baik yaitu sebesar $66,7 \%$, sedangkan pengguna mengatakan sangat setuju pada fitur - fitur yang ada dalam aplikasi ini dapat berjalan dengan baik yaitu sebesar 33,3\%.

5. Dari hasil pengumpulan data kuisioner yang terkumpul dari 3 user maka didapat hasil akhir yaitu bahwa sebanyak $41,7 \%$ mengatakan setuju, sedangkan 58,3\% mengatakan sangat setuju.

Analisa hasil uji coba dari aplikasi ini berjalan cukup lancar dan pengguna menjalankan aplikasi ini dengan baik. Tampilan dari aplikasi sudah cukup baik dan mudah dioperasikan oleh petugas dari Dinas Pekerjaan Umum dan Penataan Ruang Kota Malang. Namun masih perlu ditambahkan beberapa fungsi untuk lebih menunjang aplikasi lebih baik dan lebih mempermudah Petugas Dinas Pekerjaan Umum dan Penataan Ruang Kota Malang untuk mengoperasikan aplikasi ini.

\subsection{Kesimpulan}

Berdasarkan analisa yang telah dilakukan hasil pengujian dan pengukuran aplikasi yang telah dibangun ini dapat disimpulkan bahwa :

1. Aplikasi Tanggap Cepat Pengaduan Infrastruktur di Kota Malang dapat mempermudah masyarakat dalam melakukan pengaduan terkait infrastruktur di Kota Malang

2. Aplikasi Tanggap Cepat Pengaduan Infrastruktur di Kota Malang dapat membantu Dinas Pekerjaan Umum dan Penataan Ruang (Dinas PUPR) dalam menerima aduan masyarakat, dan penyaluran laporan ke setiap bidang-bidang yang menangani

\section{DAFTAR PUSTAKA}

[1] S. L. Poltak, Reformasi Pelayanan Publik: Teori Kebikakan, dan Implementasi. Jakarta, 2005.

[2] M. Naomi, "Analisa Dan Perancangan Sistem Pengaduan Mahasiswa Berbasis Web (Studi Kasus: Universitas Mercu Buana Kranggan)," JUSIBI (Jurnal Sist. Inf. dan Bisnis Digit., vol. 1, no. 5, 2019.

[3] B. Nugroho, "PHP dan MySQL dengan editor Dreamweaver MX," Yogyakarta Andi, 2004. 
[4] H. Nazaruddin Safaat, "Android Pemrograman Aplikasi Mobile Smartphone dan Tablet PC Berbasis Android," Inform. Bandung, 2011.

[5] M. A. Rahman, I. Kuswardayan, and R. R. Hariadi, "Perancangan dan Implementasi RESTful Web Service untuk Game Sosial Food Merchant Saga pada Perangkat Android," Tek. Inform. ITS, vol. 1, no. 2, 2013. 